\title{
Women and Tenun Sumba Local Knowledge
}

\author{
Rustina Untari \\ r_untari@unika.ac.id \\ Soegijapranata Catholic University, Pawiyatan Luhur Iv No 1 Semarang Indonesia
}

\begin{abstract}
Women weavers have an important role in East Sumba woven handicraft. Sumba weaving has been around for centuries and still exists with all its authenticity. This paper will discuss the role of women weaver in Sumba especially in the preservation of weaving craft. The research was conducted by ethnography method, deepening the life of the weavers in East Sumba. The study found women weavers do transfer local knowledge to the younger generation. The process of technology transfer (transfer of local knowledge) naturally as a mother raises her child. There is a clear stage to do.
\end{abstract}

Keywords - local knowledge, craft, women crafter, weaving, Sumba

\section{Introduction}

East Sumba has several areas that traditionally produce weaving. Sumba weaving has an important role in people's lives because of the need for cultural activities. Sumba weaving is very well known as an exotic weaving with motifs related to local culture and using natural colors.

Historically, Sumba weaving has been around for centuries. Phenophene shows that manufacture still survives, so we assume that it is people who truly believe in the skill of making weaving from other parties who are also active in their knowledge, needed for the younger generation. The process of making weaving has become a local knowledge developed in the community, actively developed and disseminated.

Related to what is meant by the Sumba weaving business is women. Therefore we consider it as a woman who needs local knowledge and then disseminates it to young generation. The main question of this research is how to try Sumba women to spread the local knowledge needed for the younger generation to survive until now

\section{Methods}

We conducted ethnography research. We explore the daily live East Sumba community. Observation on all of the community we checked the plants of natural color. We also pay attention whether weaving process can be told by everyone. We interviewed the crafters about how they learned and how they thought about it to the children or the young generation. Then we analyzed to explain the process of maintaining Sumba weaving.

The study was conducted in Lambanapu village and Kambera sub-district, East Sumba district. Kambera District is one of the famous weaving areas in Sumba. The study was conducted in 2018, but in 2014 there were observations. 


\section{Results And Discussions}

\subsection{East Sumba Weaving at the glance}

Sumba Weaving is known as "tenun Ikat" its mean "Tied weaving". The yarn has to tie before dying. They use rope made from palm leaf at some part follow the motif, then dipped at natural color for hours. This step will repeat until all of the color stick at yarn, untied then weaving.

Sumba weaving will use for cultural activities, i.e. wedding, funeral as a Marapu Cultural, and also for daily (party) cloth. At the funeral the corpse wrapping with the best weaving. Family, relatives or colleagues will come and bring the weaving. Sumba people believe that life in the afterlife is identical with life in the world, so they provide clothes and stock for the corpse in the afterlife world [1] .

Nowadays the activities of weaving have begun developing. At the beginning they made weaving for they own need, now it's become a commercial handicraft business to marketed locally, nationally, and internationally [2].

\subsection{Local Knowledge in East Sumba Weaving}

The terminology of Local knowledge came from Anthropology's Geertz (1983). Greetz defined local knowledge as "practical, collective and strongly rooted in a particular place" that forms an "organized body of thought based on the immediacy of experience" (p. 75). [3]

Three Local Knowledge in East Sumba Weaving, there are Natural dyes, design of Sumba weaving, and the process of weaving.

In the case of Sumba weaving, there is some knowledge that can be classified into several groups:

1. Knowledge of preparing threads ready to be weave

2. Designing /Drawing motif

3. Thread binding technique

4. Natural Dyes

5. Coloring technique

6. Weaving season

7. Planting and Harvesting of natural Colors (renewable)

Sumba people have a very valuable traditional knowledge in terms of natural dye utilization. They use a variety of natural resource for coloring purposes such as for body tattoo and woven coloration. Both of them are cultural heritage for their ancestor, but for the first mention activities -body tattoo- are now rarely performed. While coloring of woven is still maintained. [4]

Knowledge of fabric production is not kept in secrecy. Everybody can explain about Sumba Fabric production. All of the knowledge is not written yet, they only follow the memory and words of mouth in the community. Therefore we can classify the Sumba Weaving knowledge as tacit knowledge.

There are many forms of local knowledge, I e descriptive, declarative, procedural, and concept [5]. And Cuningham et al said that traditional cotton textile dye processes demonstrate local people's sophisticated local knowledge of natural product chemistry. Every traditional textile 
is the result of this knowledge, combining the skills required for tying, mordanting, and dyeing cotton prior to weaving. [6].

\subsection{How does the knowledge is preserved and distributed}

The knowledge and skills of weaving in Sumba have been preserved since time immemorial. This can be seen from the use of all techniques and materials used (especially coloring techniques). Plants for dying grow wild everywhere.

Local knowledge that keeps in years mean there is transfer knowledge from senior to the junior citizen in some community. It is informal education, and Sumba weaving knowledge is tacit knowledge. Tacit knowledge is abstract and can be communicated only through the active involvement of the teacher. [7]

The weaving itself falls into the women's domain, men often produce the weaving implements (Fischer 1979:13) [8]. Therefore knowledge transfer also mostly done by women. The process can be described below:

Women will invite their children to help them in the weaving work or children will voluntarily approach and help their parents/mothers or neighbors by doing weaving work. Therefore weaving production is learned by young generation through observation, participation, imitation. It is taught informally and the woman does as a mentor. A mentor, therefore, has always been considered one who draws upon a deep knowledge base to teach and guide. Mentoring as an important transfer mechanism for knowledge within organizations has grown significantly in the past couple of decades [9]

In Informal Education within daily live, women have an important role. Women as primary educators in indigenous communities, have sustained their frameworks and associated knowledge systems for millennia, even while undergoing major social upheavals as a result of transformative forces beyond their control. [10]. The recognition and restoration of indigenous women's knowledge through support of their efforts to pass it to future generations would enhance sustainable use of natural resources (Mikkelsen 2005).

\section{Conclusions}

1. The knowledge and skills of weaving in Sumba have been preserved since time immemorial. This can be seen from the use of all techniques and materials used (especially coloring techniques).

2. Weaving production is learned by young generation through observation, participation, and imitation. It is taught informally and the woman does as a mentor. Women are the main actor and transfer that knowledge to her children or community through the natural process. In Informal Education within daily life, women have an 
important role. Women as primary educators in indigenous communities have sustained their frameworks and associated knowledge systems for millennia, even while undergoing major social upheavals as a result of transformative forces beyond their control. [10]

\section{Acknowledgment}

1. Thank you to Kemenristek Dikti, the funding of the research in the PKLN (Foreign Cooperation Research) scheme

2. Thank you to Prof. Radhika Gajjala from Blowing green State University, OHIO USA, as a research partner in PKLN Scheme, who with Dr Vinnie Gajjala participated and supported in the field study

3. Thank you to Prof.Ridwan Sanjaya, research fellow from Soegijapranata Catholic University who is very supported this research.

4. Thank you to East Sumba people especially the crafter from Lambanapu and Prauliu Village, Kambera District, who are very helpful and open in providing the data

\section{References}

[1] Lukman Solihin, "MENGANTAR ARWAH JENAZAH KE PARAI MARAPU : UPACARA KUBUR BATU PADA MASYARAKAT UMALULU , SUMBA TIMUR DELIVERING SPIRITS TO PARAI MARAPU :," Pus. Penelit. dan Pengemb. Kebud. Jl. Jenderal Sudirman-Senayan, Gedung E Lantai 9, Jakarta 12041, 2013.

[2] Murniati and M. Takandjandji, “ANALISIS USAHA TENUN IKAT BERBASIS PEWARNA ALAM DI KABUPATEN SUMBA TIMUR: Kasus di Kecamatan Kambera dan Umalulu," Din. Kerajinan dan Batik Maj. Ilm., vol. 33, no. 1, pp. 67-84, 2016.

[3] H. Shafii and S. M. S. Musa, "Urban Transportation : Issue and Solution," J. TechnoSocial, vol. 2, pp. 31-46, 2010.

[4] T. Herawati and Y. Andalina, "Local Knowledge of East Sumba People," Proc. 2nd Int. Symp. Indones. Wood Res. Soc. Bali12-13 Novemb. 2010, no. November 2010, pp. 978-979, 2010.

[5] C. Antweiler, "Local Knowledge as a Universal Social Product : A General Model and a Case from Southeast Asia," pp. 165-190, 2016.

[6] A. B. Cunningham, I. M. Maduarta, J. Howe, W. Ingram, and S. Jansen, "Hanging by a Thread: Natural Metallic Mordant Processes in Traditional Indonesian Textiles 1," Econ. Bot., vol. 65, no. 3, pp. 241-259, 2011.

[7] C. Dhanaraj, M. A. Lyles, H. K. Steensma, and L. Tihanyi, "Managing tacit and explicit knowledge transfer in IJVs: The role of relational embeddedness and the impact on performance," J. Int. Bus. Stud., vol. 35, no. 5, pp. 428-442, 2004.

[8] J. Forshee, "Shifting visions," Asia Pacific J. Anthropol., no. 778409444, pp. 37-41, 2007.

[9] D. A. Leonard, "Using Mentoring and Storytelling to Transfer Knowledge in the Workplace," J. Manag. Inf. Syst. /Summer, vol. 18 No1, no. June 2001, pp. 95-114, 2011.

[10] A. M. Zobolo and Q. N. Mkabela, "Traditional knowledge transfer of activities practised by Zulu women to manage medicinal and food plant gardens," African J. 
Range Forage Sci., vol. 23, no. 1, pp. 77-80, 2006. 
